September 2021

\title{
Constructivism in Action: A Dynamic Group Process in Defining and Applying Principles of Social Justice
}

\author{
Tanupreet Suri \\ Touro College \\ Leslie Woolson \\ Arianna Trott \\ Marty Apodaca \\ M. Kathryn Brammer
}

See next page for additional authors

Follow this and additional works at: https://trace.tennessee.edu/tsc

Part of the Counselor Education Commons, and the Scholarship of Teaching and Learning Commons

\section{Recommended Citation}

Suri, Tanupreet; Woolson, Leslie; Trott, Arianna; Apodaca, Marty; Brammer, M. Kathryn; Daniel, Dèsa Karye; Lacen, Diane; and Chávez, Thomas A. (2021) "Constructivism in Action: A Dynamic Group Process in Defining and Applying Principles of Social Justice," Teaching and Supervision in Counseling: Vol. 3 : Iss. 3 , Article 1.

https://doi.org/10.7290/tsc030301

Available at: https://trace.tennessee.edu/tsc/vol3/iss3/1

This article is brought to you freely and openly by Volunteer, Open-access, Library-hosted Journals (VOL Journals), published in partnership with The University of Tennessee (UT) University Libraries. This article has been accepted for inclusion in Teaching and Supervision in Counseling by an authorized editor. For more information, please visit https://trace.tennessee.edu/tsc. 
Constructivism in Action: A Dynamic Group Process in Defining and Applying Principles of Social Justice

\section{Authors}

Tanupreet Suri, Leslie Woolson, Arianna Trott, Marty Apodaca, M. Kathryn Brammer, Dèsa Karye Daniel, Diane Lacen, and Thomas A. Chávez 


\section{Constructivism in Action: A Dynamic Group Process in Defining and Applying Principles of Social Justice}

Tanupreet Suri, Leslie Woolson, Arianna Trott, Marty Apodaca, M. Kathryn Brammer, Dèsa Karye Daniel, Diane Lacen, Thomas A. Chávez

As a part of a multicultural course, students in a doctoral program at a university in the Southwest worked together to synthesize a definition of social justice. The constructivist process implemented in this educational experience represented social justice in action, through coconstruction of shared meaning. This definition, centered on Iris Young's (2004) Five Faces of Oppression, resulted in the following: Social justice is addressing oppression, violence, exploitation, marginalization, powerlessness, and cultural imperialism through counselors' efforts and advocacy, while promoting a critical perspective of the culture of silence. Social justice is an active, effective change on micro- and macro-levels to alter social systems and institutions, whereby improving human rights and access to resources. Social justice is actively engaging in education, advocacy, critical thinking, systemic change, and client empowerment in order to diffuse mechanisms of oppression for the purpose of assisting clients in reaching their human potential.

Keywords: counselor education, social justice, constructivism

Constructivism is an approach to counselor education which has been promoted by researchers in the field as an effective tool to target and develop counselor and counselor-educator skills (Eriksen \& McAuliffe, 2011). Specifically, constructivist-developmental approaches rely on social context, relationships, and the integration and reintegration of information through the dialectical process of external (social) and internal (self) exchange (Bandura, 1986; Piaget, 1995). Therefore, the development of self is anchored to others, and vice versa, creating an equitable environment for the coconstruction of knowledge (Dewey, 1966; Piaget, 1995; Vygotskii, 1978). Constructivism has also been identified as an approach within which inclusion is embedded, in that all perspectives and ideas are shared and included in the final product: the creation of knowledge (Dewey, 1966). This article outlines the constructivist processes implemented in the authors' educational experience. The constructivist process was implemented through an experiential course as- signment where students were asked by the instructor (the last author) to coconstruct a definition of $\mathrm{so}$ cial justice. This experience represented social justice in action, through coconstruction of shared meaning. Finally, the cocreated definition of social justice was applied to a counseling case study.

As a component of an Advanced Multicultural Counseling course held in fall 2017 at a CACREPaccredited university in the Southwestern region of the United States, seven counseling doctoral students were asked to construct a definition of social justice. The doctoral students formed three small groups and coconstructed their definitions of social justice. All seven doctoral students came together as a large group to integrate their social justice definitions through a constructivist process. This process included a collaborative discussion and subsequent development of a working definition of social justice. Ultimately, the seven doctoral students holding various intersecting identities and experiences collaborated and constructed a definition and model of social justice through a transformative process, 
Constructivism in Action

which included a large group synthesis following the cocreation of definitions in small groups.

The purpose of this operational definition is intended to add to counseling related literature and offer one representation of social justice for counselors, and perhaps even one applicable mission statement that encapsulates addressing systems of power and oppression, the impact of interpersonal and systems change, advocacy efforts, and continuous active engagement to empower clients and improve their overall well-being. The purpose of this article is to feature the engaging process of the authors, offer insight into the functionality of constructivism within an Advanced Multicultural Counseling classroom, and explicate a collaborative operational definition of social justice, extending on current literature.

Social justice has not always been considered a fundamental part of the counseling profession (Chung \& Bemak, 2011). There is a call and a clear need for counselors and those in helping professions to address systems of injustice, such as oppression, discrimination, and privilege (Decker et al., 2016). This requires that counselors have preparation and awareness, knowledge, and skills specifically aligned with social justice frameworks to provide culturally humble counseling (Chung \& Bemak, 2011; Hook et al., 2013; King \& Borders, 2019; Parrow et al., 2019; Sue et al., 2019). To discover an underpinning of social justice fitting the current paradigm, the authors offer a contextual definition of social justice with the distinction that it is entirely constructed using a socially just method, in that it honors all voices in the drafting and cocreation of the final definition and model. As a means to explore the effectiveness and applicability of such a model, the authors have included a specific case study for how it may be implemented for a client experiencing oppression.

This article is presented in two sections. The first section elaborates on the educational process of cocreating definitions in small groups; this process can be adapted into counseling courses and used as an inclusive constructivist pedagogy tool. The second section focuses on the applicability of the cocreated social justice definition and model with a case study. This process highlights how counselors may apply the coconstructed social justice definition and model with marginalized clients.

\section{The Educational Process of Cocreating Definitions and Model of Social Justice}

The seven doctoral students worked in three small groups during their Advanced Multicultural Counseling course to develop their own definitions of social justice. Their discussions were guided by literature in counselor education, psychology, and counseling (Decker et al., 2016; Fuertes \& Brobst, 2002; Gil, 2004; Goodman et al., 2004; Kiselica \& Robinson, 2001; Lee \& Rogers, 2009; Nilsson \& Schmidt, 2005; Olson et al., 2013) and included the Multicultural and Social Justice Counseling Competencies (MSJCC): Guidelines for the Counseling Profession (Ratts et al., 2015). Definitions of social justice were constructed within the three small groups, with each group creating a visual representation.

Each group's definition and context are outlined in the following three sections. The group as a whole concluded by sharing their definitions alongside their visual representation and discussions. All three definitions of social justice were refined into a unified whole, including the integration of the visual representations into a model (see Appendix A). The authors present a case study to demonstrate this integrated social justice definition and model's applicability.

\section{Small Group 1 Discussion: Social Justice Related to Systems of Power and Oppression}

The domination of social ideology, resources, and institutions, which results in privilege for one group over another, are aspects of the definition of sociopolitical oppression (Smith, 2008). The effects of oppression can be viewed as a pathogen for racism and poverty, causing enormous effects such as "environmental risk factors, physiological stress responses, psychological trauma, and community disintegration" (Smith et al., 2009, p.160). Oppression and its social and individual outcomes continue to be areas in which social justice counselors could have significant impact. Historically, socially just societies have been democratic, egalitarian, and structurally nonviolent (Gil, 2004). The overarching function of structural violence is to maintain the order of hierarchy and inequity in a society, where this violence is gradually coupled with coercive 
control resulting in the colonization of people's minds (Freire, 1970).

Chung and Bemak (2011) discuss the criticality for counselors to address restructuring systems of power and privilege to move toward justice, equity, and equality. Young's (2004) work on the five faces of oppression serve as clear definitions of power and privilege counselors can address in their work. The five faces of oppression are: violence, exploitation, marginalization, powerlessness, and cultural imperialism (Young, 2004). The culture of silence originally defined by Freire (1921) describes the overwhelming sense of powerlessness that limits people who experience oppression from talking about or describing their oppressive experiences.

Many authors have stated that social justice in the field of counseling must address power and oppression (Chung \& Bemak, 2011; Decker et al., 2016; Hoover \& Morrow, 2016). Counselors need to explicitly attend to power in and outside of the counseling relationship to address social injustices (Hoover \& Morrow, 2016). Young's (2004) descriptions of violence, exploitation, marginalization, powerlessness, and cultural imperialism provide specific descriptions for counselors to distinctly address power within the counseling relationship and outside the counseling room. This includes a culturally responsive approach, as outlined by Chung et al. (2011), as being paramount for work in social justice, specifically regarding advocacy efforts. Examples of a culturally responsive approach includes working within and understanding the local cultural context, seeking support from the community stakeholders, and creating an environment where clinicians and community members work together (Smith et al., 2009).

Small Group 1 Definition Proposal. Social justice is addressing oppression, violence, exploitation, marginalization, powerlessness, and cultural imperialism through counselors' efforts and advocacy, while promoting a critical perspective of the culture of silence.

\section{Small Group 2 Discussion: Social Justice Related to Interpersonal and Systems Change}

Micro- and macro-level understanding helps to parse the counselor's role in social justice. The
MSJCC (Ratts et al., 2015) state developmental domains that exemplify the micro level of social justice: counselor self-awareness, client worldview, and the counseling relationship. For the purposes of this article, the client worldview will be termed the client's beliefs and values, and the counseling relationship will be termed the helping relationship.

Counselor self-awareness encompasses attitudes and beliefs of the counselor and the counselor's self-realization of them (Parrow et al. 2019; Pompeo \& Levitt, 2014). Privileged and marginalized counselors are aware of their social identities, social group status, power, privilege, oppression,

strengths, limitations, assumptions, attitudes, and biases, and they possess the skills that enrich their understanding (Hoover \& Morrow, 2016; King \& Borders, 2019; Sue et al., 2019) and self-awareness of these (Ratts et al., 2015). Counselors' cultural self-awareness is a precursor for effective and culturally relevant therapy and cultural empathy (Pompeo \& Levitt, 2014; Ratts et al., 2015), which may be defined as awareness of clients' worldviews (Hall et al., 2014; Ratts et al., 2015). Counselors should have an understanding of the beliefs and values of the client, and they should listen to the stories of the client. Such stories include the biases, social identities, social group statuses, and experiences with power, privilege, and oppression (Lorié et al., 2017; Ratts et al., 2015).

The helping relationship is based on principles of advocacy, including interventions addressing the intrapersonal processes that impact privileged and marginalized clients such as employing empowerment-based theories, assisting clients in developing critical consciousness and unlearning their privilege and oppression, assessing the historical events and current issues, working in communities to better understand attitudes and beliefs, and assisting clients with self-advocacy skills (Phillips et al., 2015; Ratts et al., 2015; Zimmerman, 1995).

Furthermore, counselors need an understanding of the relevance and limitations of Western therapy for clients. The social justice counseling paradigm "uses social advocacy and activism as a means to address inequitable social, political, and economic conditions that impede the academic, career, and personal/social of individuals, families, and communities" (Ratts, 2009, p. 160). The MSJCC is a standard that was developed to address concerns of 
social injustice seen in the counseling profession and among clients. The MSJCC outlines specific competencies that guide three of the four developmental dimensions of multicultural counseling. While the first three elements specifically explore micro-level techniques to deliver multicultural counseling in a way that is competent and humble, the fourth element provides precise recommendations pertaining to macro levels of social justice as well as ways to provide appropriate counseling treatments and advocacy movements (Ratts et al., 2015).

Intrapersonal, interpersonal, institutional, community, public policies, and international and global affairs guide macro-level systems, according to the MSJCC (Ratts et al., 2015). To improve the lives of individuals who experience oppression, social systems such as government, politics, and economy must change (Gil, 2004). According to the MSJCC (2015), it is the counselor's responsibility to get involved with the societal organizations/institutions that create values, norms, resources, procedures, and policies that continually oppress marginalized clients. It is imperative the counselor address situations with clients (Ratts et al., 2015) when faced with macro-level dilemmas among underserved groups (Gil, 2004). Gil (2004) examined the ways social institutions and community play a large role in public policy and the creation of "just and unjust societies" (p. 4). Mutualism, cooperation, equality, and liberty are some indicators of just societies, whereas societies deemed unjust present with exploitation, individualism, and competition. Ultimately, unjust societies do not adhere to community values that just societies hold due to differing standards that guide policies and keep the dominant society in control, lending to much needed reform and social action (Gil, 2004).

Small Group 2 Definition Proposal. Social justice is an active, effective change on micro levels and macro levels to alter social systems and institutions, whereby improving human rights and increasing resources.

\section{Small Group 3 Discussion: Social Justice Related to Active Engagement}

Social justice is a complex construct, especially because there are different ways in which social justice is understood based on context, field of interest, and desired goals or outcomes (Buettner-Schmidt \& Lobo, 2011; Olson et al., 2013). The actionable component of social justice can shift based on the field, professional identities, and scope of practice. In counseling, empowerment plays out in both counselors and clients.

Counselors are empowered in decision making to assist clients in achieving specific goals, all while seeking an overall improvement in quality of life (American Counseling Association, 2014). The empowerment of clients allows for the development of greater agency and decision making in clients' own lives, which can have a ripple effect throughout client communities (McWhirter, 1991). Social justice education is important for both counselors and clients. Working with marginalized and oppressed populations, counselors are expected to be properly trained in multicultural competencies (Fuertes \& Brobst, 2002; Ratts et al., 2015). Social justice education may assist clients that are so steeped in oppression they may not realize they are being marginalized (Young, 2004).

Several authors (Goodman et al., 2004; Nilsson \& Schmidt, 2005; Trusty \& Brown, 2005) have stated the importance of training novice counselors in the tenets of social justice. In promoting social justice, counselors can work with clients to recognize and critically identify when instances of oppression are occurring within a client's life or community. Kiselica and Robinson (2001) write how active counselors practicing social justice can serve as advocates on behalf of clients. Fully understanding mechanisms of oppression requires both client and counselor to think critically about the systems they are engaged with, and how they can create reflective and reflexive action that disrupt systems that marginalize - leading toward the ultimate goal of counselors practicing advocacy and social justice: systemic change.

Interestingly, the counselor domain is typically located in the individual, in terms of assisting a client through difficulties of life. Yet, while counselors excel at addressing individual client challenges, 
tackling larger systemic issues can be a difficult endeavor (Lee \& Rodgers, 2009). Counselors who practice social justice and advocacy with clients can begin to sow the seeds of systemic transformation. With each individual client, there is an opportunity to engage at different levels that create incremental change, largely impacting families, communities, and institutions.

\section{Small Group 3 Definition Proposition. Social} justice is actively engaging in education, advocacy, critical thinking, systemic change, and client empowerment in order to diffuse mechanisms of oppression for the purpose of assisting clients in reaching their human potential.

\section{Large Group Synthesis: Integrated Social Justice Definition and Model}

Each of the small groups framed social justice with different emphases. The unified social justice definition aims to link the three areas: (a) address systems of power and oppression through advocacy, (b) impact interpersonal and systems change, and (c) encourage continuous active engagement. The integrated definition of social justice discusses mechanisms through which oppression is enacted and permitted, including identifying issues of silence and invisibility in marginalized populations, deconstructing and labeling systems of oppression and privilege in order to critically engage with and make visible those systems, and taking an actionoriented stance, pointing to specific ways in which counselors can intervene and honor their clients' experiences and humanity. The model that emerged from this large group synthesis illustrates the applicability to client cases (see Appendix A).

In summary, the convergence of the three definitions led to the following integrated definition of social justice (See Table 1): Social justice is addressing oppression, violence, exploitation, marginalization, powerlessness, and cultural imperialism through counselors' efforts and advocacy, while promoting a critical perspective of the culture of silence. Social justice is an active, effective change on micro levels and macro levels to alter social systems and institutions, whereby improving human rights and increasing resources. Social justice is actively engaging in education, advocacy, critical thinking, systemic change, and client empowerment in order to diffuse mechanisms of oppression for the purpose of assisting clients in reaching their human potential.

Ultimately, the inclusion of all doctoral student voices created a more holistic and nuanced definition of social justice. This constructivist process, in turn, embodied its own goal of creating a model for social justice and the process of coconstruction allowed for equity and space for all perspectives. In opposition to the "banking system" of learning, which Friere (1970) framed as oppressive and dehumanizing, we as students were empowered to create our own meaning, thereby honoring the value of our perspective and dismantling hierarchy in the learning process. The final operational definition not only illustrates the constructivist process, but also emphasizes a practical application of social justice that benefits individual clients and the community,

Table 1

The Educational Process of Co-Creating Definitions of Social Justice

\begin{tabular}{|c|l|l}
\hline Small groups & \multicolumn{1}{c}{ Small group definitions } \\
\hline Small Group Definition 1 & $\begin{array}{l}\text { Social justice is addressing oppression, violence, } \\
\text { exploitation, marginalization, powerlessness, and cultural } \\
\text { imperialism through counselors' efforts and advocacy, } \\
\text { while promoting a critical perspective of the culture of } \\
\text { silence. }\end{array}$ & $\begin{array}{l}\text { Social justice is addressing oppression, violence, exploitation, } \\
\text { marginalization, powerlessness, and cultural imperialism through } \\
\text { counselors' efforts and advocacy, while promoting a critical } \\
\text { perspective of the culture of silence. Social Justice is an active, } \\
\text { effective change on micro- and macro-levels to alter social } \\
\text { systems and institutions, whereby improving human rights and } \\
\text { increasing resources. Social justice is actively engaging in } \\
\text { education, advocacy, critical thinking, systemic change, and client } \\
\text { empowerment in order to diffuse mechanisms of oppression for } \\
\text { the purpose of assisting clients in reaching their human potential. }\end{array}$ \\
\hline Small Group Definition 2 & $\begin{array}{l}\text { Social Justice is an active, effective change on micro- and } \\
\text { macro-levels to alter social systems and institutions, } \\
\text { whereby improving human rights and increasing resources }\end{array}$ & $\begin{array}{l}\text { Social justice is actively engaging in education, advocacy, } \\
\text { critical thinking, systemic change, and client empowerment } \\
\text { in order to diffuse mechanisms of oppression for the } \\
\text { purpose of assisting clients in reaching their human } \\
\text { potential. }\end{array}$ \\
\hline & & \\
\hline
\end{tabular}


and ideally challenges caustic societal norms. A case study is provided to assist the reader with understanding how the authors applied the integrated social justice definition and model.

\section{Case Study}

On August 7, 2004, Cyntoia Denise Brown, selfidentifying as biracial (16 years old), was arrested for the murder of Johnny Michael Allen (43 years old). According to court records (Brown v. State of Tennessee, 2014), Brown was walking near a Sonic Drive-In when Allen (whom she did not know at the time) picked her up in his truck. Allen offered to buy Brown dinner and allow her to stay at his home for the night. Once arriving at Allen's home, Brown was shown several guns in the home, which were allegedly owned by Allen. According to police reports, Allen allegedly bought sex from Brown. Sometime during the night, Brown reported feeling unsafe and stated "Allen reached for a gun." Brown told prosecutors that she feared for her life and shot Allen, killing him. After the incident, Brown was arrested by police. Allen's two guns were in her possession, as well as his car and wallet.

During Brown's trial, it was discovered that Brown was forced by Garion "Cut Throat" McGlothen (24 years old) to have sex with older men. This detail is important as child sex trafficking can have traumatic implications for the victims (Hopper \& Gonzalez, 2018). Forensic psychiatrist Dr. William Bernet testified on behalf of Brown as to whether she was competent to stand trial, if she understood the implications of waiving her Miranda rights prior to talking to police, and whether she should be tried as an adult. Dr. Bernet stated, "I know we had to make sure she was competent, so we certainly did an evaluation of competence. I am not sure if we went any further at that point on any other mental health issues." Brown was tried and sentenced as an adult, receiving life in prison with the possibility of parole when she is 67 years old. In 2011, new evidence presented in an appeal indicated that Brown suffers from fetal alcohol syndrome (FAS). Dr. Richard Adler testified that at the time of the incident that although Brown was physically 16 years old, she had the mental capacity of a 10 -year-old. The court case is ongoing with no outcome at this time. In 2017, Brown was 29 years old (Brown v. State of Tennessee, 2014).

\section{Application of Model}

Part One: Systems of Power and Oppression. Brown's case has elements of violence, exploitation, marginalization, powerlessness, and cultural imperialism. Prior to the age of 16, Brown was exploited by being forced into sex work through violence and intimidation. Through lack of resources and available choices, Brown had no power to change her situation. In addition, Brown's circumstances and her experience in the court system impacted her social standing and limited her future potential to contribute to society (Young, 2004). Beyond being marginalized as a sex worker and a woman of color, Brown struggled with symptoms of FAS, thus it is likely her mother was marginalized for her drug and alcohol use, illustrating a historic chain of oppression. This chain of oppression can have long-lasting impact on a child's growth and development (Wilhoit et al., 2017). Brown's sentence (being tried and sentenced as an adult and receiving a sentence of life in prison with the possibility of parole at age 67) is an example of using norms established by the ruling class as a consequence for murder (Young, 2004). This is a type of cultural imperialism within the United States judicial system, in that there is no opportunity for context, especially if the context is that of experienced oppression (Young, 2004).

Part one of the model suggests Brown's situation be shared widely as a form of public advocacy, in order to dismantle the culture of silence around the case, and other cases like it. For this to be effective, it is important to name the ways in which she was oppressed, as outlined earlier. By specifically identifying the mechanisms by which oppression is enacted and permitted, we provide the opportunity for addressing them and effectively intervening, as described in part two of the model.

Part Two: Interpersonal and Systems Change. The micro levels and macro levels must be addressed as they pertain to this case, in order to address social justice and effect change. In Brown's case, the micro level includes FAS, the impact of her mother's drug use, the relationship she had with her mother, the abuse that occurred in the home, the foster care she experienced, and the adoption that occurred. Children across the fetal alcohol spectrum disorders (FASDs) are at increased risk for specific 
neuropsychological deficits, secondary disabilities, and mental health problems, including learning disabilities, behavioral disorders, and attention-deficit/hyperactivity disorder (ADHD; Fryer et al., 2007; Peadon \& Elliott, 2010). Drug use in the mother can affect the child physiologically, cognitively, and behaviorally.

Of the adolescents with FAS, $61 \%$ have been in legal trouble and $35 \%$ of those who are older than age 12 have been incarcerated at some point in their lives, according to the Office of Juvenile Justice and Delinquency Prevention (OJJDP, 2012). Children who experience parental substance misuse are removed from their homes more than any other reason. Once removed from their home, $16 \%$ of children are moved five or more times (Burd et al., 2011). Unfortunately, FAS makes it difficult for children to form relationships with foster parents and other community members, and impulsivity and behavior issues do not cultivate a stable home environment (Jones, 2004).

Established stable foster homes create the potential for positive outcomes for both the child and the family. Bonding with adults and being able to utilize resources in the community is especially beneficial for children who are in foster care; however, it has been found that children with FAS have a difficult time forming relationships. Behavior dysregulation and challenging impulsive behaviors increasingly affect the child's relationship with their foster families, increasing the chances for removal and providing less stability (Wilhoit et al., 2017). It should be addressed as to whether Brown had her biological/material needs met for survival, as well as assess whether her development and social/psychological needs were met.

Finally, the macro perspective should also be considered; it is important to understand human or sex trafficking and the trauma this can produce. Such trauma may cause the individual to experience symptoms of posttraumatic stress disorder (PTSD). Potential traumatic experiences endured include abuses in the context of the trafficking situation such as, psychological abuse, lack of basic human necessities, physical violence, and sexual violence. This can result in self-blame, uncontrollability, and learned helplessness, which is associated with depression (Hopper \& Gonzalez, 2018). Trafficking victims with complex PTSD may have symptoms such as difficulty modulating moods, amnestic or dissociative episodes, chronic shame, and difficulty trusting others (Lederer \& Wetzel, 2014). Such symptoms would likely interfere with self-identification and help-seeking in victims of human trafficking (Hopper, 2004). The helping relationship should involve the counselor or social advocate understanding their own bias and assumptions in this type of case as well as understanding the micro level or world of the client.

Part Three: Active Engagement. Promoting health education within schools and communities is a fundamental step in systemic change (Center for Disease Control, 2013; Tang et al., 2008). Partnerships with community health agencies could be used to host community-based workshops where education and preventative information on FASDs can be disseminated. Counselors can collaborate with other community providers to deliver information and connect community members to resources.

Furthermore, counselors can use their role to take a more active stance in promoting increased health education for students and families within the school system. Advocacy on this level might consist of assessing educational opportunities. In Brown's case, she was working toward her bachelor's degree, and had a position as an unpaid consultant for the Juvenile Justice System. Through educational opportunity, the client can regain some power and control.

By the fall of 2017, Brown had been incarcerated for 13 years. This span included all of her adult life and formative developmental years. Brown knew nothing of a stable life outside the walls of a prison. The aftercare needed after release for her to have an attempt at a successful life would be substantial. Here, a counselor could advocate for Brown in terms of housing and resources for transition out of prison. A counselor could assist Brown's reentry into society by connecting her to job opportunities, finding housing opportunities, and referring her to organizations and groups that might act as support systems. Depending on the community Brown entered, she could be eligible for federal bonding, which might potentially mitigate employers' concerns about hiring her. In addition to supporting Brown in securing her basic needs, a counselor 
could advocate for her reentry into society by countering preconceived notions that her community might have about her.

For Brown, systemic poverty, racism, and gaps in her legal process were some of the many factors that contributed to a difficulty-laden upbringing and unjust prison sentence. Counselors can challenge laws aimed at punishing vulnerable individuals who do not have a voice in modern society. For example, mandatory sentencing can be employed unjustly and has proven to be an ineffective crime deterrent (Fradella, 2000; Luna, 2017; Mascharka, 2000).

Individual client empowerment is a goal of counselors (American Counseling Association, 2014). From an overarching view, empowering clients in the criminal justice system is a growing need that counselors can work toward improving through advocacy efforts. Nonetheless, advocacy can seem cumbersome if larger societal issues are not brought to light and challenged as such; there are many ways in which counselors can assist incarcerated clients by addressing systemic marginalization. One method is to encourage clients to take advantage of prison-based learning and correspondence courses in order to further clients' education and support their efforts in doing so. Another method includes counselors working with clients reentering society after an extended sentence by discussing the changes society has encountered since they were imprisoned. After a client is released, counselors can continue to employ advocacy on the client's behalf by helping clients navigate the complexities of employment, housing, connecting to support groups, networking with other people, and reiterating that they do have rights and are not societal pariahs.

\section{Conclusion}

The final operational definition of social justice presented earlier illustrates the collaborative efforts of doctoral students and their constructivist process to explicate a practical application of social justice methods that will ideally challenge caustic societal norms that impact clients and the community. The collective group agreed that the case of Cyntoia Brown was an excellent example of social unjust; therefore, her story was utilized to epitomize the functional approach of our social justice model.
Following the large-group synthesis, the authors discussed the constructivist process and its place in understanding social justice. Social justice, at its most effective, is able to adapt to the malleable sociocultural environment in which it exists. In order to mitigate this necessary fluidity, one author suggested defining social justice was necessarily an ongoing process. Therefore, the construction of a model and definition is extended to future students. We share our definition and model as a starting point, and our constructivist process as a potential building block. Empirical research studies could further solidify the model and cocreated definition established in this project.

\section{References}

American Counseling Association. (2014). 2014 ACA code of ethics. https://www.counseling.org/resources/aca-code-of-ethics.pdf

Bandura, A. (1986). Social foundations of thought and action: A social cognitive theory. Prentice-Hall.

Brown v. State of Tennessee. (Court of Criminal Appeals of Tennessee at Nashville March 11, 2014).

Buettner-Schmidt, K., \& Lobo, M. L. (2011). Social justice: A concept analysis. Journal of Advanced Nursing, 68(4), 948-958. https://doi.org/10.1111/j.1365-2648.2011.05856.x

Burd, L., Cohen, C., Shah, R., \& Norris, J. (2011). A court team model for young children in foster care: The role of prenatal alcohol exposure and fetal alcohol spectrum disorders. The Journal of Psychiatry \& Law, 39(1), 179-191. https://doi.org/10.1177/009318531103900107

Centers for Disease Control. (2013). Make a difference at your school. Chronic Disease. Paper 31. https://healthyplacesindex.org/wp-content/uploads/2017/12/2013_unt_make_difference_school.pdf

Chung, R. C. Y., \& Bemak, F. P. (2011). Social justice counseling: The next steps beyond multiculturalism. SAGE.

Chung, R. C. Y., Bemak, F., \& Grabosky, T. K. (2011). Multicultural-social justice leadership strategies: Counseling and advocacy with immigrants. Journal for Social Action in Counseling and Psychology, 3(1), 57-69. https://doi.org/10.33043/JSACP.3.1.86-102

Decker, K. M., Manis, A. A., \& Paylo, M. J. (2016). Infusing social justice advocacy into counselor education: Strategies and recommendations. Journal of Counselor Preparation and Supervision, $8(3)$.

Dewey, J. (1966). Democracy and education: an introduction to the philosophy of education. The Macmillan Company.

Eriksen, K., \& McAuliffe, G. (2011). Handbook of counselor preparation: Constructivist, developmental, and experiential approaches. SAGE.

Fradella, H. F. (2000). Mandatory minimum sentences: Arizona's ineffective tool for the social control of driving under the influence. Criminal Justice Policy Review, 11(2), 113-135. https://doi.org/10.1177/0887403400011002002

Freire, P. (1921). The politics of education. Bergi \& Garvey. Freire, P. (1970). Pedagogy of the oppressed. Herder and Herder. Fryer, S., McGee, C., Matt, G., Riley, E., \& Mattson, S. (2007). Evaluation of psychopathological conditions in children with heavy prenatal alcohol exposure. Pediatrics, 119, 733-741. https://doi.org/10.1542/peds.2006-1606 
Fuertes, J. N., \& Brobst, K. (2002). Clients' ratings of counselor multicultural competency. Cultural Diversity and Ethnic Minority Psychology, 8(3), 214-223. https://doi.org/10.1037/10999809.8.3.214

Gil, D. G. (2004). Perspectives on social justice. Reflections: Narratives of Professional Helping, 10(4), 32-39.

Goodman, L. A., Liang, B., Helms, J. E., Latta, R. E., Sparks, E., \& Weintraub, S. R. (2004). Training counseling psychologists as social justice agents: Feminist and multicultural principles in action. The Counseling Psychologist, 32(6), 793-836. https://doi.org/10.1177/0011000004268802

Hall, K. G., Barden, S., \& Conley, A. (2014). A relational-cultural framework: Emphasizing relational dynamics and multicultural skill development. The Professional Counselor, 4(1), 71-83.

Hook, J. N., Davis, D. E., Owen, J., Worthington, E. L., \& Utsey, S. O. (2013). Cultural humility: Measuring openness to culturally diverse clients. Journal of Counseling Psychology, 60(3), 353-366. https://doi.org/10.1037/a0032595

Hoover, S. M., \& Morrow, S. L. (2016). A qualitative study of feminist multicultural trainees' social justice development. Journal of Counseling \& Development, 94(3), 306-318. https://doi.org/10.1002/jcad.12087

Hopper, E. (2004). Underidentification of human trafficking victims in the United States. Journal of Social Work Research and Evaluation, 5(2), 125-136.

Hopper, E. K., \& Gonzalez, L. D. (2018). A comparison of psychological symptoms in survivors of sex and labor trafficking. Behavioral Medicine, 44(3), 177-188. https://doi.org/10.1080/08964289.2018.1432551

Jones, K. (2004). Successfully raising resilient foster children with fetal alcohol syndrome: What works. Envision: The Manitoba Journal of Child Welfare, 3(1), 1-18.

King, K. M., \& Borders, L. D. (2019). An experimental investigation of white counselors broaching race and racism. Journal of Counseling \& Development, 97(4), 341-351. https://doi.org/10.1002/jcad.12283

Kiselica, M. S., \& Robinson, M. (2001). Bringing advocacy counseling to life: The history, issues, and human dramas of social justice work in counseling. Journal of Counseling \& Development, 79(4), 387-397. https://doi.org/10.1002/j.15566676.2001.tb01985.x

Lederer, L. J., \& Wetzel, C. A. (2014). The health consequences of sex trafficking and their implications for identifying victims in healthcare facilities. Annals of Health Law, 23, 61-91.

Lee, C. C., \& Rodgers, R. A. (2009). Counselor advocacy: Affecting systemic change in the public arena. Journal of Counseling \& Development, 87(3), 284-287. https://doi.org/10.1002/j.15566678.2009.tb00108.x

Lorié, Á., Reinero, D. A., Phillips, M., Zhang, L., \& Riess, H. (2017). Culture and nonverbal expressions of empathy in clinical settings: A systematic review. Patient Education and Counseling, 100(3), 411-424. https://doi.org/10.1016/j.pec.2016.09.018

Luna, E. (2017). Mandatory minimums. Reforming criminal justice: A report of the Academy for Justice on bridging the gap between scholarship and reform, 4, 117-146.

Mascharka, C. (2000). Mandatory minimum sentences: exemplifying the law of unintended consequences. Fla. St. UL Rev., 28, 935.

McWhirter, E. H. (1991). Empowerment in counseling. Journal of Counseling \& Development, 69(3), 222-227. https://doi.org/10.1002/j.1556-6676.1991.tb01491.x

Nilsson, J. E., \& Schmidt, C. K. (2005). Social justice advocacy among graduate students in counseling: An initial exploration. Journal of College Student Development, 46(3), 267-279.
Office of Juvenile Justice and Delinquency Prevention. (2012). A first drink before a first breath: Fetal alcohol spectrum disorders. https://www.ojjdp.gov/newsletter/238981/sf_2.html

Olson, C. J., Reid, C., Threadgill-Goldson, N., Riffe, H. A., \& Ryan, P. A. (2013). Voices from the field: Social workers define and apply social justice. Journal of Progressive Human Services, 24(1), 23-42. https://doi.org/10.1080/10428232.2013.740407

Parrow, K. K., Sommers-Flanagan, J., Cova, J. S., \& Lungu, H. (2019). Evidence-based relationship factors: A new focus for mental health counseling research, practice, and training. Journal of Mental Health Counseling, 41(4), 327-342. https://doi.org/10.17744/mehc.41.4.04

Peadon, E., \& Elliott, E. (2010). Distinguishing between attentiondeficit hyperactivity and fetal alcohol spectrum disorders in children: Clinical guidelines. Neuropsychiatric Disease and Treatment, 6, 509-515. https://dx.doi.org/10.2147\%2Fndt.s7256

Phillips, N. L., Adams, G. E., \& Salter, P. S. (2015). Beyond adaptation: Decolonizing approaches to coping with oppression. Journal of Social and Political Psychology, 3(1), 365-387. http://dx.doi.org/10.23668/psycharchives.1786

Piaget, J. (1995). The essential Piaget. (H. E., Gruber \& J. J. Vonèche, Eds.). J. Aronson.

Pompeo, A. M., \& Levitt, D. H. (2014). A path of counselor selfawareness. Counseling and Values, 59(1), 80-94. https://doi.org/10.1002/j.2161-007X.2014.00043.x

Ratts, M. (2009). Social justice counseling: Toward the development of a "fifth force" among counseling paradigms. Journal of $\mathrm{Hu}$ manistic Counseling, Education, and Development, 48, 160-172. https://doi.org/10.1002/j.2161-1939.2009.tb00076.x

Ratts, M. J., Singh, A. A., Nassar-McMillan, S., Butler, S. K., \& McCullough, J. R. (2015). Multicultural and social justice counseling competencies: Guidelines for the counseling profession. Journal of Multicultural Counseling and Development, 44(1), 28 48. https://doi.org/10.1002/jmcd.12035

Smith, L. (2008). Positioning classism within counseling psychology's social justice agenda. The Counseling Psychologist, 36(6). https://doi.org/10.1177/0011000007309861

Smith, L., Chambers, D. A., \& Bratini, L. (2009). When oppression is the pathogen: The participatory development of socially just mental health practice. American Journal of Orthopsychiatry, 79(2), 159-168. https://doi.org/10.1037/a0015353

Sue, D. W., Sue, D., Neville, H. A., \& Smith, L. (2019). Counseling the culturally diverse: Theory and practice. John Wiley \& Sons Inc.

Tang, K. C., Nutbeam, D., Aldinger, C., St Leger, L., Bundy, D., Hoffmann, A. M., \& Morales, S. (2008). Schools for health, education and development: a call for action. Health Promotion International, 24(1), 68-77. https://doi.org/10.1093/heapro/dan037

Trusty, J., \& Brown, D. (2005). Advocacy competencies for professional school counselors. Professional School Counseling, 259265.

Vygotskiı̌, L. S. (1978). Mind in society: The development of higher psychological processes. Harvard University Press.

Wilhoit, L., Scott, D., \& Simecka (2017). Fetal alcohol spectrum disorders: Characteristics, complications, and treatment. Community Mental Health Journal, 53, 711-718. https://doi.org/10.1007/s10597-017-0104-0

Young, I. (2004). Five faces of oppression. In L. Heldke \& P. O'Connor (Eds.), Oppression, privilege, \& resistance: Theoretical perspectives on racism, sexism, and heterosexism (pp. 37-63). McGraw-Hill.

Zimmerman, M. A. (1995). Psychological empowerment: Issues and illustrations. American Journal of Community Psychology, 23, 581-600. 


\section{Appendix A:}

Integrated Social Justice Model
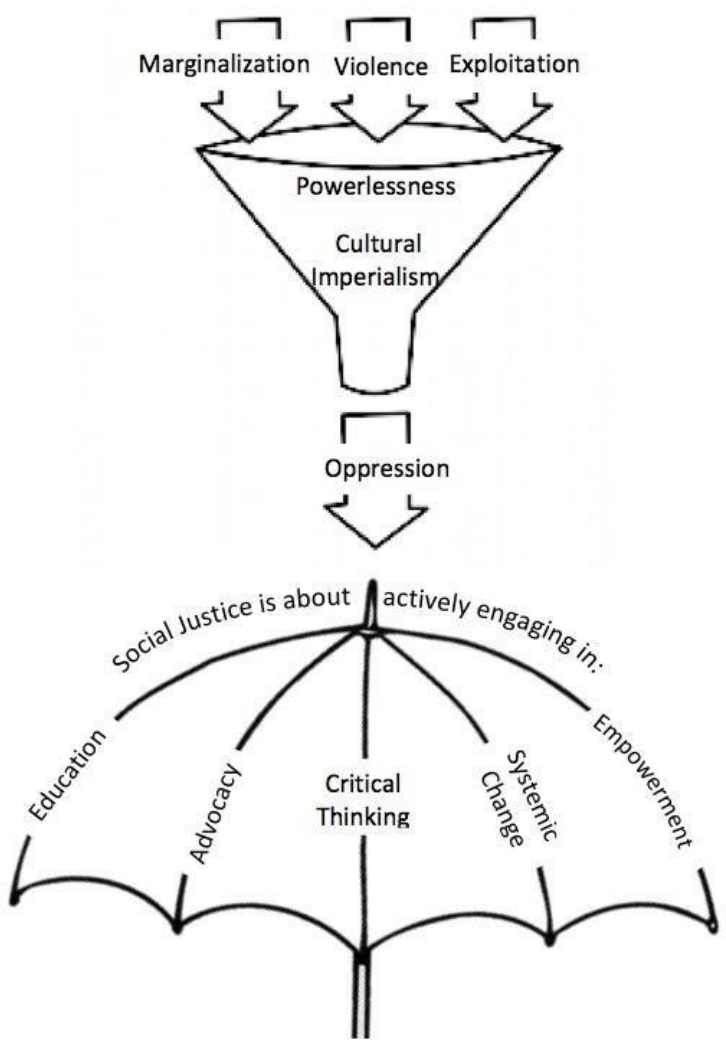

in order to diffuse mechanisms of oppression for the purpose of assisting clients in reaching their human potential

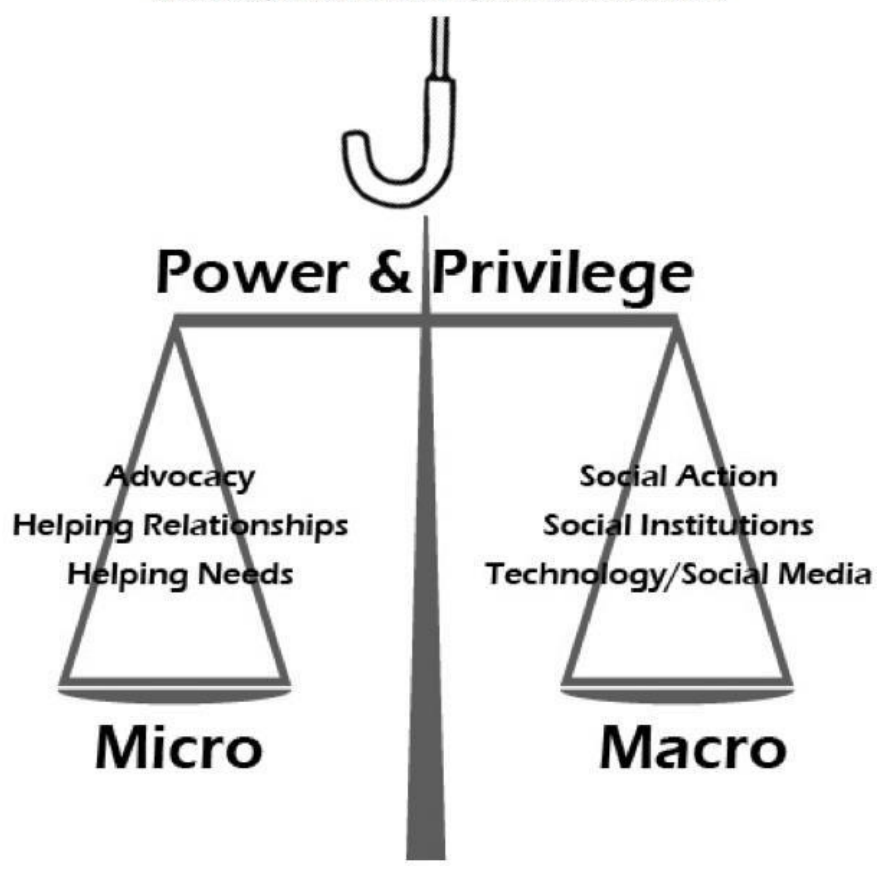

